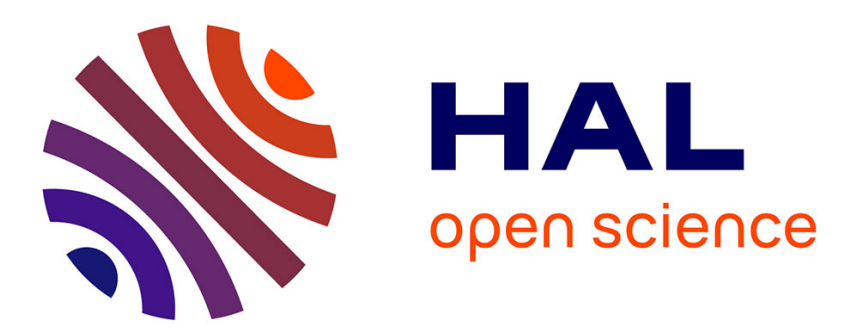

\title{
Back to Fasad... and the PPNB controversy. Questioning a Levantine origin for Arabian Early Holocene projectile points technology
}

Vincent Charpentier, Rémy Crassard

\section{- To cite this version:}

Vincent Charpentier, Rémy Crassard. Back to Fasad... and the PPNB controversy. Questioning a Levantine origin for Arabian Early Holocene projectile points technology. Arabian Archaeology and Epigraphy, 2013, 24 (28-36), 10.1111/aae.12011 . hal-01828579

\section{HAL Id: hal-01828579 \\ https://hal.science/hal-01828579}

Submitted on 4 Jul 2018

HAL is a multi-disciplinary open access archive for the deposit and dissemination of scientific research documents, whether they are published or not. The documents may come from teaching and research institutions in France or abroad, or from public or private research centers.
L'archive ouverte pluridisciplinaire HAL, est destinée au dépôt et à la diffusion de documents scientifiques de niveau recherche, publiés ou non, émanant des établissements d'enseignement et de recherche français ou étrangers, des laboratoires publics ou privés. 


\section{Back to Fasad... and the PPNB controversy. Questioning a Levantine origin for Arabian Early Holocene projectile points technology}

For decades, so-called Fasad points have been discovered in Oman and the UAE. These lithic projectile points have been until now fossiles directeurs (or defining artefacts) for Early Holocene human occupation prior to the development of the Arabian Neolithic. It appears that many different types of points are described in the literature as Fasad points, but the actual variability of the archaeological discoveries leads to the necessity for reassessment and clarification of the very definition of this type of artefact. We propose here a new definition of the Fasad points with the creation of sub-types. We also discuss the trend of using this lithic type as a marker for the diffusion of PPNB technology towards the south-east from the Mediterranean Levantine Neolithic core area.

Keywords: Oman, United Arab Emirates, PPNB, lithic technology, Fasad point, Qatar B

\author{
Vincent Charpentier ${ }^{1}$ and \\ Rémy Crassard ${ }^{2}$ \\ ${ }^{1}$ CNRS-Inrap, UMR 7041, \\ Maison de l'Archéologie et de \\ l'Ethnologie, F-92023 Nanterre, \\ France \\ e-mail: vincent.charpentier@inrap.fr \\ ${ }^{2}$ CNRS-Université Lyon 2, UMR \\ 5133, Maison de l'Orient et de la \\ Méditerranée, F-69004 Lyon, \\ France
}

e-mail: remy.crassard@mom.fr

\section{Introduction: the Fasad points and their implication in the development of Arabian prehistory}

At the southern border of the immense sand dune desert of the Rub' al-Khali there is a Bedouin locality called Fasad, recently renamed al-Hashmān. This area is located in Dhofar, the Sultanate of Oman's western region, and was first surveyed by amateur archaeologists. The collected stone tools were then studied by the Harvard Archaeological Expedition (Pullar 1974). It is only in the late 1980s that 'Fasad' was associated with a specific type of lithic point, after the discovery in the Wahiba Sands (eastern Oman) of a lithic industry composed of Neolithic bifacial arrowheads as well as some projectile points made on 'worked blanks' (Edens 1988), the latter being called 'Fasad points' in reference to Pullar's 1974 article. In the mid-1990s, a 'Fasad facies' was created (Charpentier 1996) as a new lithic techno-complex. This was based on discoveries of new sites in the Ja'alan region (Sharqiya province, Oman) and on an inventory of all Fasad points found in the Oman peninsula. Since then, Fasad is the eponym of an early Holocene culture of Oman and the United Arab Emirates (UAE).
All these discoveries have led various archaeologists, including ourselves, to call every projectile point made on a worked blank with a tang a Fasad point. This now needs to be reassessed, as not any tanged arrowhead made on a flake or blade blank can be called a Fasad point. Thanks to the latest analyses of both old and new lithic series, it appears that in terms of typology and technology, the Fasad points present a high rate of variability in their own shapes and in the method used to produce the blank. We propose here to define what should be called a Fasad point today. We will also apply our results to a persistent controversy concerning the origin of the Neolithic in the Gulf, and more broadly in the Arabian Peninsula, by comparisons with Pre-Pottery Neolithic B (PPNB) industries from the Levant.

\section{The different types of Fasad points}

A projectile point is called a Fasad point as long as it is a pointed flake or blade with a tang clearly shaped by any kind of retouch. The artefact is usually not retouched anywhere other than the tang, but in some cases retouch 
appears along one or two edges, or is carried out at the distal part (the tip) of the blank.

The analysis of the material from the locality of Fasad (Charpentier \& Crassard 2012) shows a production of projectile points made on thin laminar blanks, usually slightly irregular in shape. Dhofar province in Oman, up to the Yemeni border, marks the south-western edge of the Fasad points' distribution in the Oman peninsula (Fig. 1). Many Fasad points have been collected from surface sites (e.g. Zarins 2001), and a few from stratified and dated contexts (e.g. Cremaschi \& Negrino 2002). The points from surface sites are often of the same type originally found at Fasad: tanged arrowheads on a thin, narrow, long and blade-like blank. Edges are often irregular, sometimes slightly curved. This same type of point has been identified in the Wahiba Sands (Edens 1988) and along the Indian Ocean shoreline of Oman (Charpentier et al. 2012). Some other Fasad points in Dhofar present a thicker and sometimes wider blank which is almost always a flake or a thick lami- nar flake. Technologically, this indicates that the blank was not produced the same way.

To the north-east of the Wahiba Sands, the material found in the Ja'alan area is somewhat different. On eight particular sites, Fasad points have been described (Charpentier 2008). At Ra's al-Jinz RJ-37, the eleven discovered points were made on flakes with a naturally pointed shape on the distal extremity. These blanks, often wide and thick, give a robust appearance to the obtained points (Charpentier 1991). Still in the Ja'alan, the site of AlHaddah BJD-1 has produced the richest collection of Fasad points in Oman, with more than sixty specimens, complete or fragmentary (Charpentier, Cremaschi \& Demnard 1997). There is high variability in the shapes and dimensions of the points, both in their raw material and in the shape of the blanks obtained: flakes with a central ridge, sometimes laminar flakes, but never proper blades or bladelets as is seen in the material from Fasad or from the Wahiba Sands.

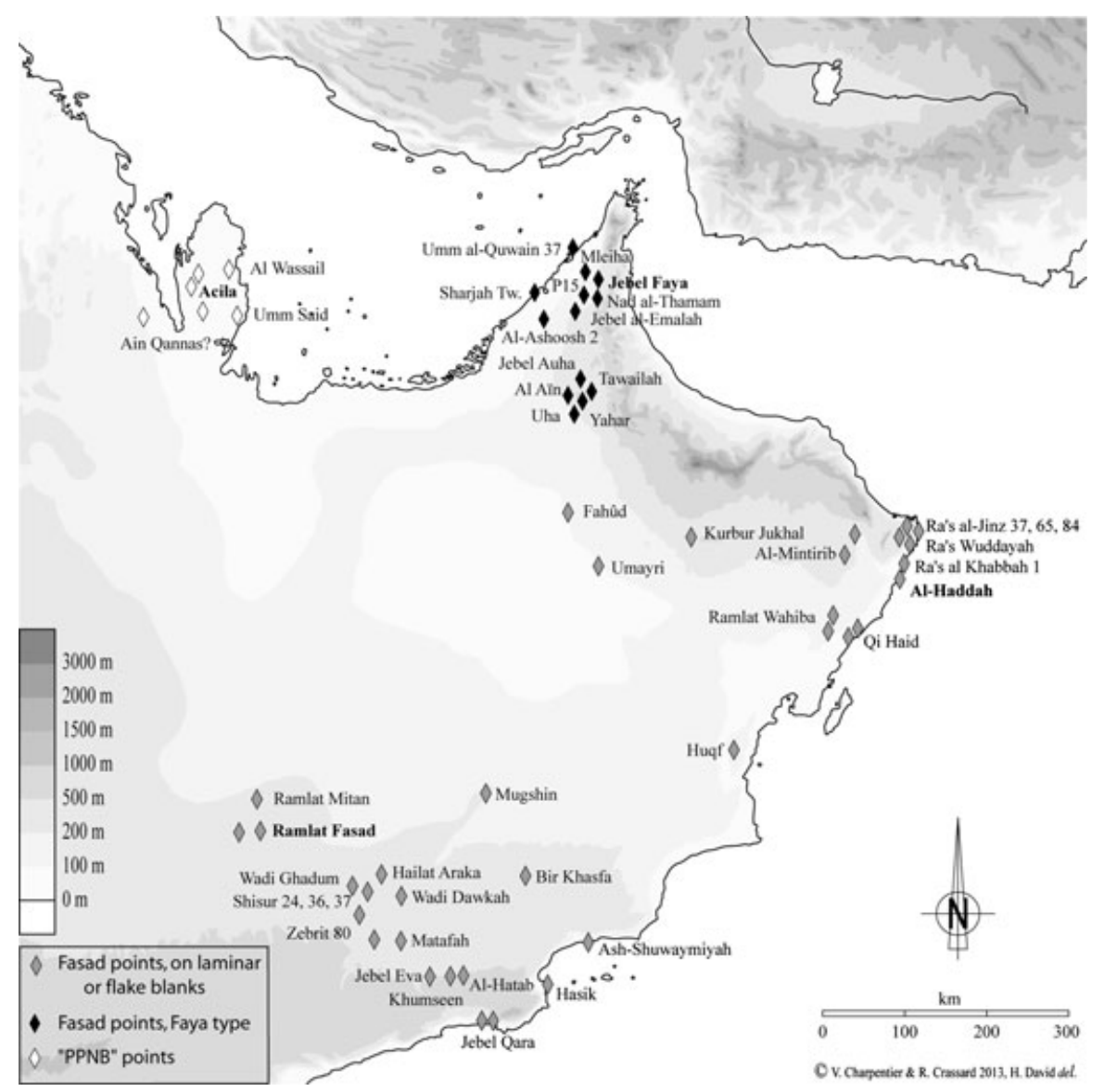

Fig. 1 .

A general map of the Oman peninsula and the distribution of Early Holocene projectile points. 
The UAE represent the north-eastern edge of the presence of Fasad points, in particular the points found in the Faya area (Uerpmann, Potts \& Uerpmann 2009). They were made on short, thin, regular blades and bladelets and present directly retouched tangs.

The Fasad facies chronology has for a long time been based on conjecture. Exact chronology is still imprecise for many regions. Some scholars have seen in these points an Aterian influence, dated to the Late Pleistocene (McClure 1994; Scerri 2012). This hypothesis is certainly incorrect, as the Fasad points, like the rest of the tools, are different from what is known in the Aterian culture. First, Edens attributed the Fasad points to a period between the fifth and the third millennium cal. BC (Edens 1982). In Dhofar, in the rock shelters of Jebel al-Qara, Fasad points have been dated by radiocarbon to the eighth millennium cal. BC (Cremaschi \& Negrino 2002): KR-108 (8750 \pm 50 BP; 7910-7690 cal. BC) and KR-213 (8720 $\pm 60 \mathrm{BP} ; 7740-7590 \mathrm{cal}$. BC). Other stratified sites have been found in Dhofar, such as Hasik (M. Tosi, personal communication) on the coast, which is still undated. Three OSL- and AMS-dated inland sites in Dhofar Nejd have yielded a few Fasad points: Al-Hatab (level 1), Ghazal (level 2) and Khumseen (level 5), providing an approximate range between 10,000 and 7000 BP (Hilbert, Rose \& Roberts 2012). In the UAE, Fasad points have been discovered inland around Al-Ain, along the coast at Sharjah Tower (Millet 1988; Kallweit 2003), and the points from Faya NE01 and $\mathrm{Nad}$ al-Thamam have been attributed to a period ranging between 8450-7760 and 7000-6450 cal. BC (Uerpmann, Potts \& Uerpmann 2009). The Fasad facies is thus broadly datable to between the ninth and seventh millennium cal. BC.

\section{The other types of points made on blades}

At Acila (or al-Aseila) site 36 in Qatar, small points with an average length of $6 \mathrm{~cm}$ have been found. They are very regular with a straight profile and dorsal parallel ridges. These points have a tang that is barely formed by invading parallel and bifacial retouch, made by pressure technique. The distal extremity also presents bifacial retouch if the blank has not provided the desired pointed shape (Inizan 1980, 1988). These industries have been associated with the broader terminology of the Qatar B Group (Kapel 1967). This typological group is characterised by what Kapel called the Blade-Arrowhead culture, in reference to the Levantine terminology at that time. Blanks are blades de plein débitage and were produced on small naviform cores with two opposed striking platforms. This process of flaking (débitage) proceeds alternately, obtaining a few straight and regular blades for each core (Pélegrin \& Inizan, this volume). This technology is well known in the Levantine records and is a peculiarity of the PPNB lithic industries. Naviform debitage was first described by J. Cauvin (1968), and appeared around 8200 -8000 cal. BC at Mureybet, in Syria, and spread throughout the Levant beginning in the Early PPNB around 7600 cal. BC (Abbès 2003). In north-east Saudi Arabia, a few sites have been mentioned as having this kind of blade production (Masri 1997), and Qatar represents its south-eastern limit of expansion. This type of debitage disappears during the Late or Final PPNB around 6000 cal. BC. Naviform debitage and the production of regular blades that are sometimes transformed by pressure retouch into Amuq points, which are very similar to the Acila points, are thus compelling evidence for a PPNB presence in Arabia (Fig. 2).

In contrast to the points from Acila, the Wa'shah points found in Hadramawt, Yemen, are made by a method of debitage free of influence from the Levant (Crassard 2008a, 2008b). Obtaining predetermined pointed blades by a unidirectional convergent laminar method on semitournant cores is indeed very different from naviform technology. Points were then made only on these pointed blades, exclusively by direct and abrupt retouch of the basal extremity (Fig. 2). The 'Wa'shah method' is tentatively dated to the Early Holocene and is particular to this region of central-south Arabia, between Hadramawt and Dhofar.

\section{A reassessment of the definition of Fasad points through a typo-technological approach}

Archaeologists have systematically based their interpretations on typology when referring to the Fasad points, to the detriment of the technological component. The result is great confusion, and it would appear to be difficult to compare them with each other. As we seek to name typologically a particular type of point, rather than a real techno-complex, and as long as Fasad points are not properly dated chronometrically or stratigraphically, it is difficult clearly to define a facies. Nevertheless, the consistency of the Fasad point as a type throughout the Oman peninsula is a good indicator of an archaeological reality. We will then keep the name Fasad, but with a differentiation of three types: 

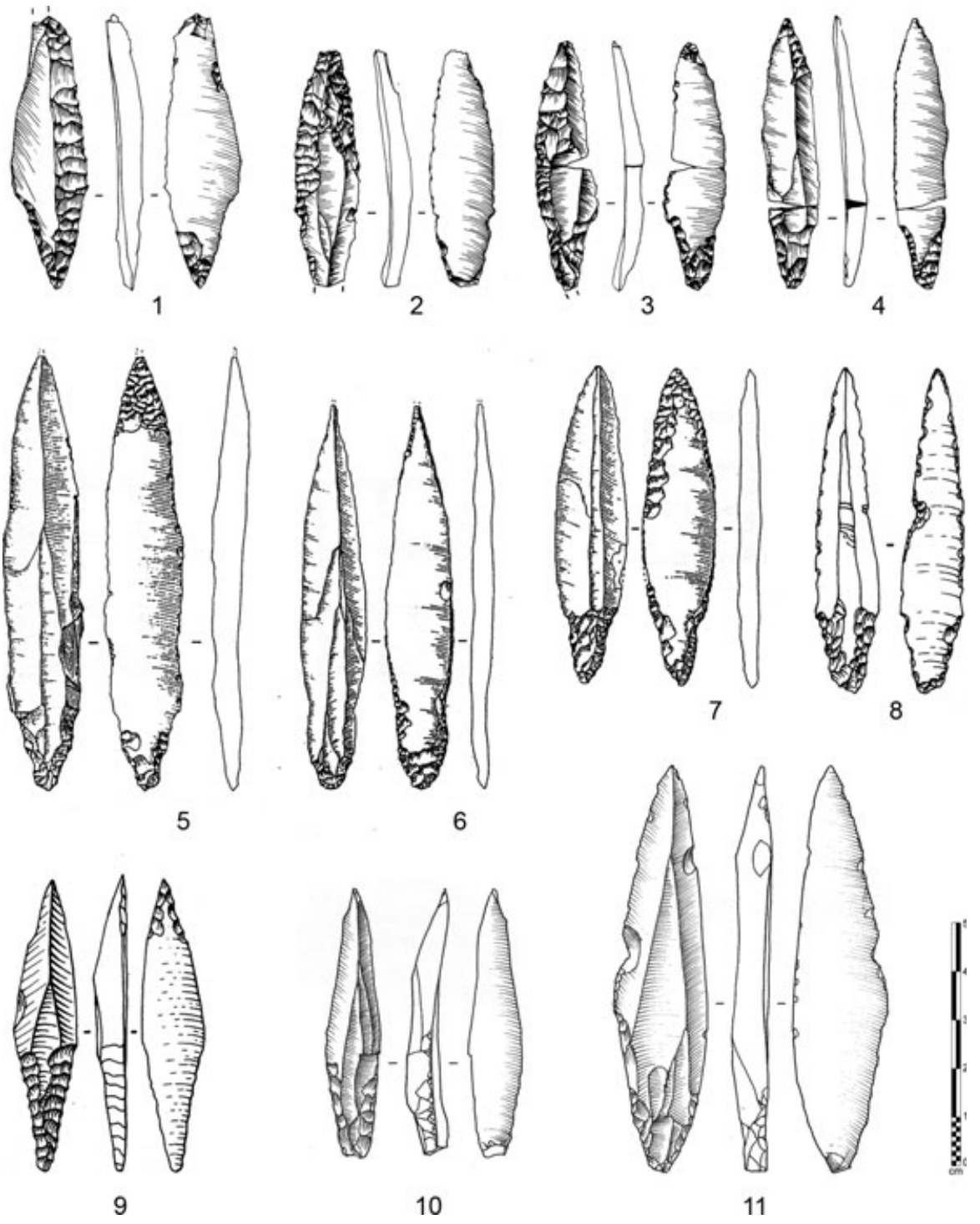

Fig. 2.

Projectile points from traditions other than Fasad: 1-4. Acila points (Qatar, Inizan 1988); 5-8. Byblos points (South Levant, Cauvin 1997); 9. Amuq point (South Levant, Cauvin 1997); 10-11. Wa'shah points (Yemen, Crassard 2008b).

\section{Type 1}

The Fasad point sensu stricto (Fig. 3) is a long flake or laminar blank with retouched tang. The blank is usually thin and long, often with irregular edges, or a fairly thick flake with a natural point at the distal extremity. The tang is clearly and sophisticatedly shaped. The tang is often made by direct retouch, but also by inverse, alternate (sensu Inizan et al. 1995) or bifacial retouch. This type is known in Dhofar: in Jebel al-Qara, the southern Rub' al-Khali, the Nejd and the coasts. It is also known in the Wahiba Sands and the coasts of north-east Oman. It may also be present in the UAE, in the Al-Ain region of the Abu Dhabi Emirate.

\section{Type 2}

Fasad points of the Faya tradition (Fig. 4) are made on thin, short blanks with regular edges. They are often prismatic regular pointed bladelets. The retouch is present only on the tang and is mainly direct and abrupt. The tang is clearly shaped, but can also be in the continuity of the lateral edges. This type is known in the Sharjah Emirate in the UAE, at Faya and Nad al-Thamam sites and perhaps in the Al-Ain region. 

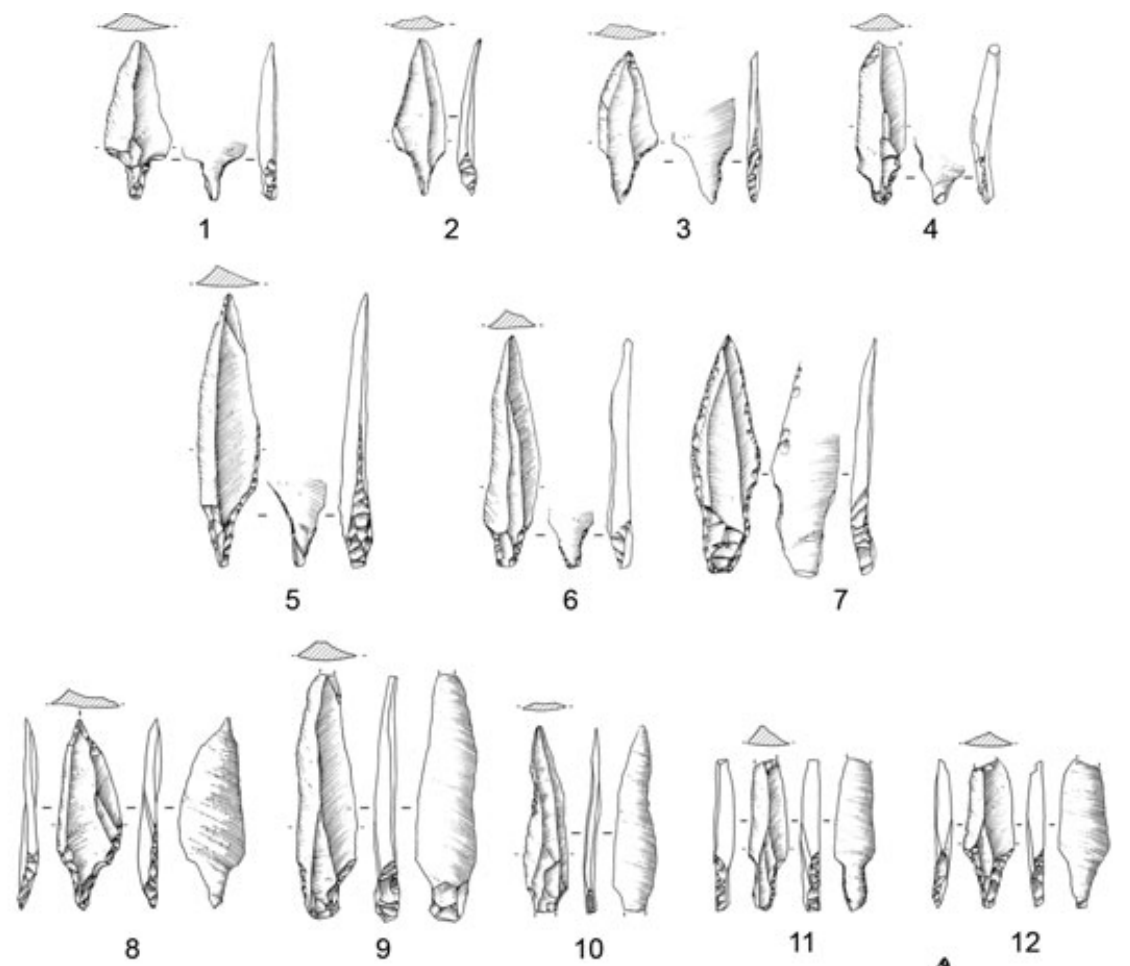

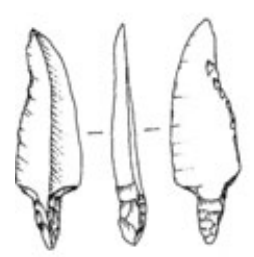

13

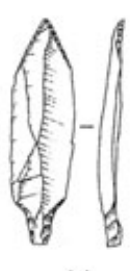

14
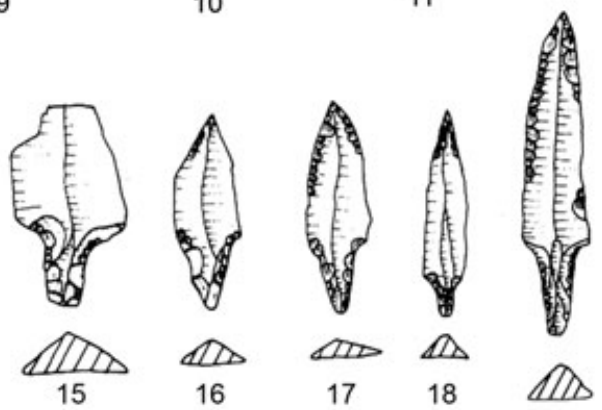

12
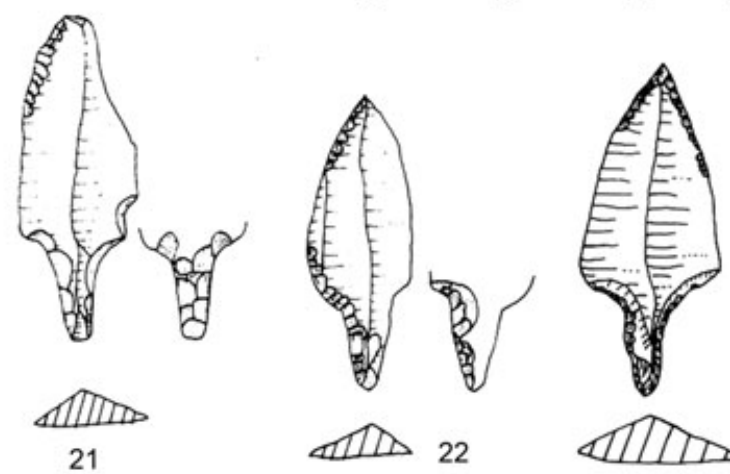

19

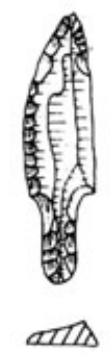

20

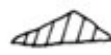

22

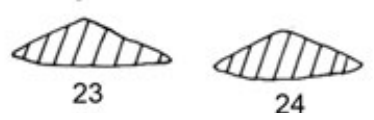

Fig. 3 .

Fasad points sensu stricto: 1-7. Jennings collection (Ramlat Fasad, drawings G. Devilder); 8-12. Hendrick collection (Ramlat Fasad/al-Hashman, drawings G. Devilder); 13-14. Jabal al-Qara (Cremaschi \& Negrino 2002); 15-24. Dhofari sites (Zarins 2001).

Type 3

The Fasad point of the Al-Haddah tradition (Fig. 5) is made on a short, thick flake, usually irregular in shape. A natural pointed or cutting (transverse) edge is used as the distal part. This type presents high variability in the final shapes. The tang is made by all types of retouch — direct, 

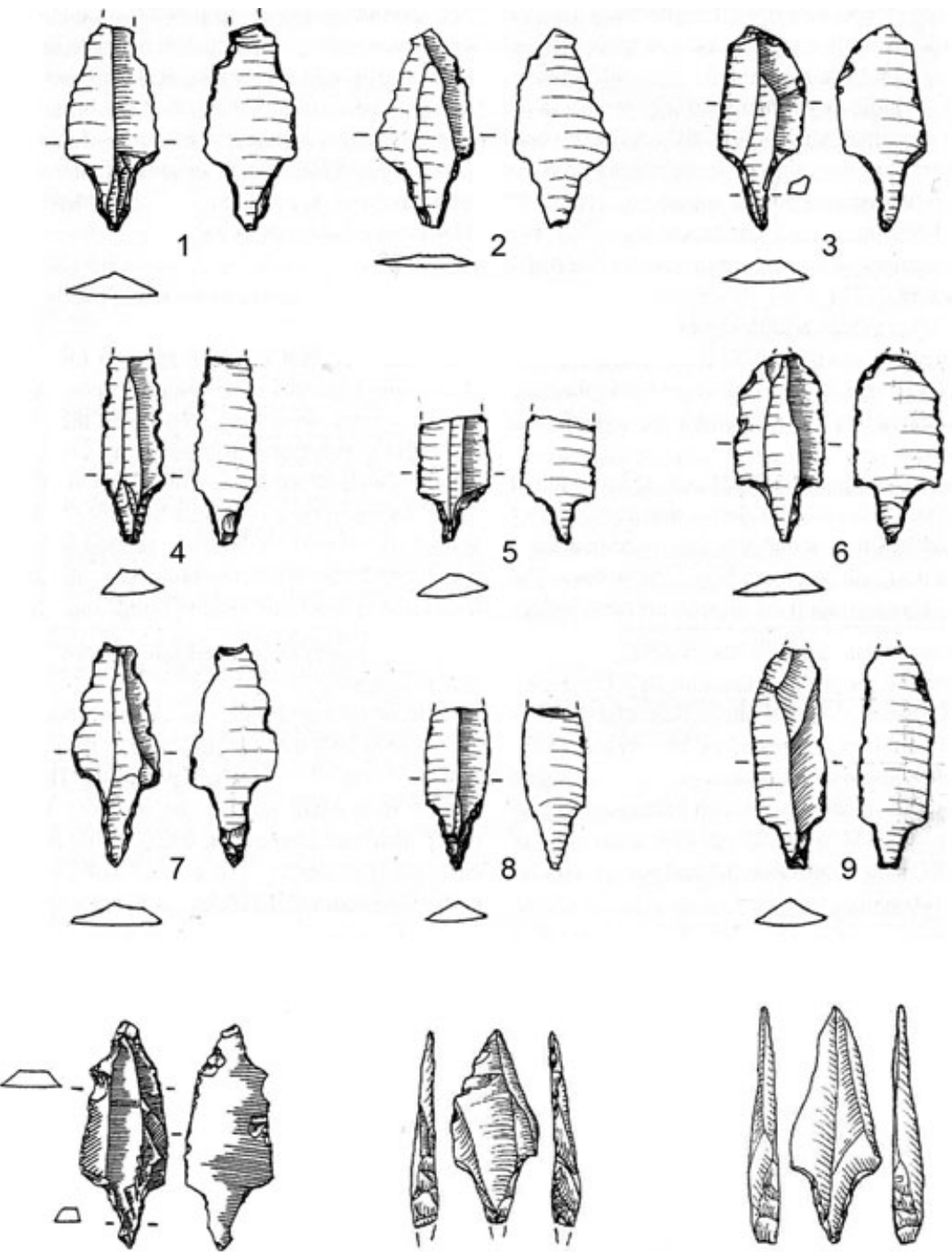

10

11

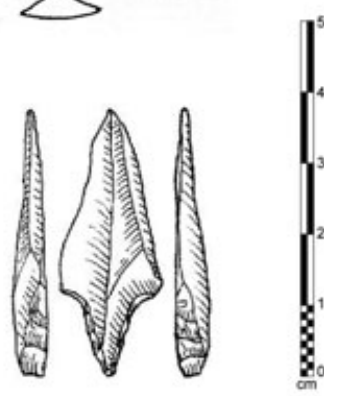

12

Fig. 4.

Fasad points of the Faya tradition: 1-3. Nad al-Thamam (UAE, Uerpmann, Potts \& Uerpmann 2009); 4-9. FAY-NE01 (UAE, Uerpmann, Potts \& Uerpmann 2009); 10. Sharjah Tower (Millet 1988); 11-12. Rothfels collection Al-Ain Museum (Kallweit 2003; NB: scale not mentioned on original illustration).

inverse, alternate and bifacial. This type is known in the Ja'alan region of north-east Oman and possibly in Dhofar, in the Nejd and at Jebel al-Qara (Zarins 2001: fig. 18/14c, $15 \mathrm{e}, 87 \mathrm{a})$.

All these points can be dated between 9000 and 7000 cal. BC, but caution is needed as some other types of points, showing the same ubiquitous simplicity of shape, could also be much later, such as examples from Hadramawt (Crassard 2008a: fig. 152) and along the Wahiba coasts (Charpentier et al. 2012: fig. 2/5).

To differentiate the types of Fasad points, a technological analysis is thus needed: removal negatives on cores and scar patterns on the dorsal side of blades/flakes are good indicators for identifying the obtainment of blanks as well as debitage methods. For the points on blades or bladelets, two different methods can be observed: semi-tournant debitage and laterally prepared debitage with the search for pointed blades with Y-shaped dorsal scar patterns. In general, the production of blanks is exclusively made by unidirectional debitage. There is no indication of any use of naviform technology involved in the manufacture of Fasad points. For the points on flakes, the methods are diverse. A pointed distal extremity was clearly sought, but sometimes a cutting transversal distal edge could be 

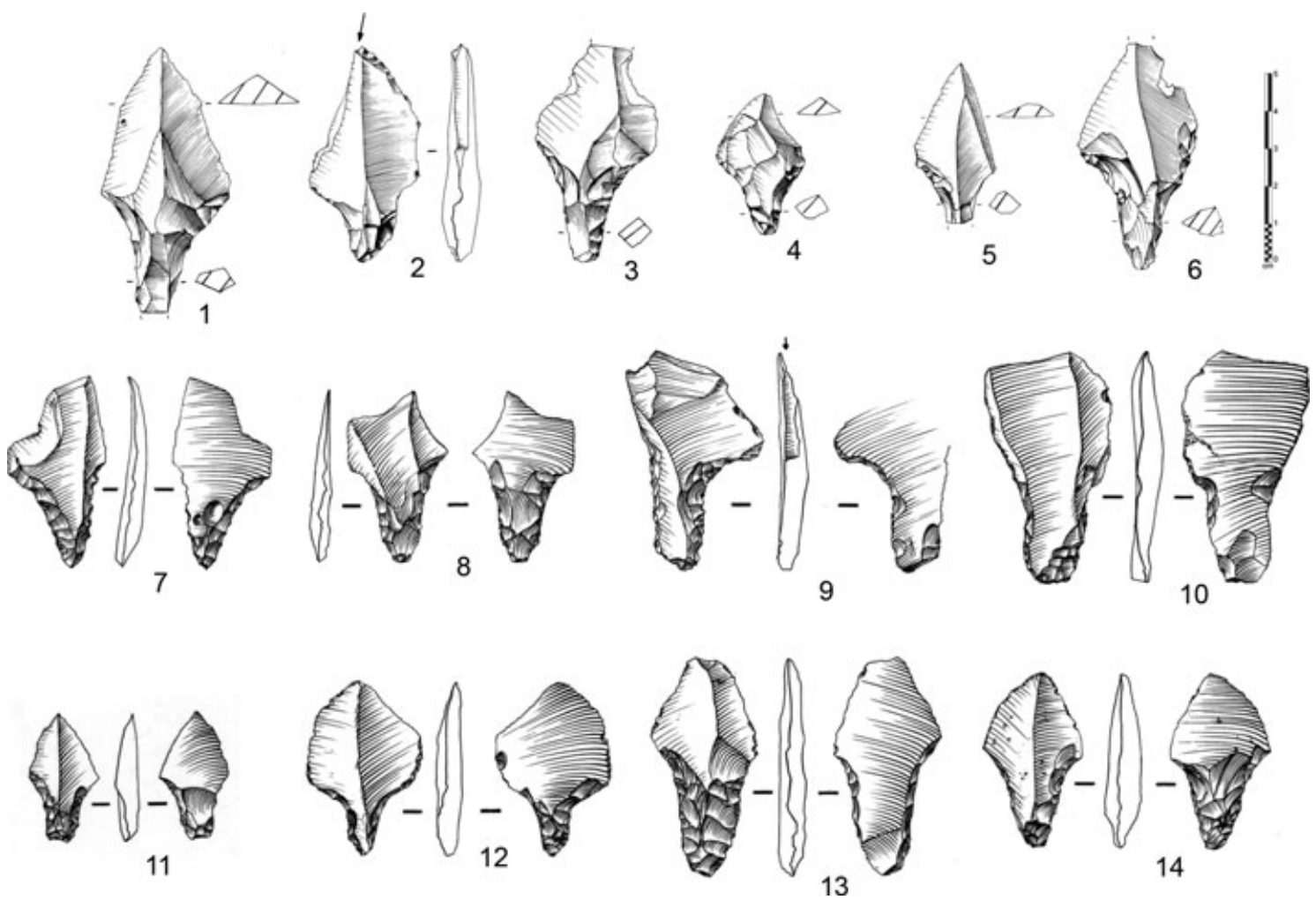

Fig. 5 .

Fasad points of the Al-Haddah tradition: 1-6. Ra's al-Jinz RJ-37 (Charpentier 1991); 7-14. Al-Haddah BJD-1 (Charpentier et al. 1997).

used. We can in any case conclude that the retouch is not usually very frequent on the body of the projectile point, as usually the tang is the only retouched part of the Fasad points. Fasad points on flakes appear to be more expediently obtained.

The technological study is thus a good indicator for interpreting traditions and regional differences, but it is difficult to link the different types together. Do they reveal a real geographical dispersion or some technical convergence or reinvention? Do they show an influence from neighbouring populations with attempts to copy the arrowhead styles? At the present stage of research, such questions remain unanswered.

\section{Questioning a PPNB origin for the Fasad technology and taxonomy}

Thus, the Fasad facies is more complex than originally thought. There is also another aspect that needs to be clarified: the origins of the Fasad facies. Is it possible to find any link with PPNB technology? We must then trace the history of the development of the supposed PPNB presence in the Gulf. It was first mentioned by Mortensen and
Kapel in 1967, for the Saudi Arabian Gulf down to Qatar, where the lithic industries named as Qatar-B were studied in detail by Inizan. Since then, the scientific community appears to accept that the points attributed to the Qatar B are identical to the typical PPNB points, and that Qatar B is thus an outgrowth of the PPNB in the Arabian Peninsula. Marie-Louise Inizan (1988) warned that the technological convergence of projectile points alone is not enough to consider that relations existed between the Near Eastern and Gulf populations. In fact, what is called Qatar$\mathrm{B}$ group represents a very heterogeneous group of points.

In order to explain prehistory in the Oman peninsula, many scholars have wished to see in the Fasad point a Levantine expression. Can Fasad points be Qatar B points, thus related to the PPNB? Hence, are Fasad points PPNB points? A simple list of arguments will show that they are not:

- The two sub-types of Fasad sensu stricto and Fasad of the Faya tradition are made on laminar blanks, but none of them was produced by a standardised laminar debitage on naviform cores, that is to say bi-directional alternate with two opposed striking platforms. 
- These 'classic' Fasad points, as also observed on Wa'shah points, come from unidirectional cores.

- The other sub-type of Fasad points, of the al-Haddah tradition, clearly marks a particular group with absolutely no relation to the Levant and the PPNB.

- The different types of Fasad point have a high variability in length: the Faya points are shorter; other Fasad points are much longer than the Acila points, the latter being highly standardised.

- Acila points have tangs made by bifacial retouch, sometimes shaped by parallel pressure technique, reminiscent of Near Eastern points. The Fasad subtypes do not present any of these criteria.

- Finally, other traditions, including the Wa'shah tradition, are specific to southern Arabia and to the Oman peninsula, and have no link at all with Qatar-B or PPNB technologies.

In conclusion, there is no pertinent link between Arabian Fasad and Levantine PPNB technologies.

\section{Conclusion: towards a new scenario, prior to the emergence of the Neolithic in Arabia}

It is clear that our results go somewhat against the archaeozoological theory of a linear migration/colonisation of sheep and goats with their herders from the Levant (Uerpmann, Potts \& Uerpmann 2009; Drechsler 2009). Several arguments attest that domesticated animals appear to come from the Fertile Crescent, but their diffusion by PPNB Levantine groups is not yet confirmed. Recent research in the Jubbah basin has shown that a fringe of northern Arabia was occupied by much older Neolithic PPNA and PPNB groups in Saudi Arabia (Crassard et al., forthcoming) and it is now demonstrated that Arabia was not uninhabited at the transition between the Late Pleistocene and the Early Holocene (Rose 2010). Fasad points, being different from PPNB points, thus provide no argument to explain the colonisation by PPNB herders of the south-east and southern Arabian Peninsula. So what is this PPNB expansion to Qatar? Did it really exist or is it a cultural convergence? It is likely that it did exist but we consider it to have been a development with no future, which stopped in Qatar with no further extension and was only located along the southern coastal fringe of the Persian Gulf? Is the introduction of this foreign tradition a clue to the introduction of a pastoral economy in Qatar? Perhaps, but it needs to be explored in much more detail.

Thus it appears plausible that the autochthonous Early Holocene population in Arabia had a role that has been too often underestimated by scholars. Recent genetic studies have revealed that present-day populations in Arabia have ancestors as far back as 60,000 years ago, that is to say well before people would have potentially come from the Levant (Fernandes et al. 2012). Local adaptation as well as the population's innovative capabilities may have provided a favourable situation for the emergence of the Neolithic in Arabia. The Arabian Neolithic would have had its own specificities, with the development of herding, sedentism and even offshore fisheries production, but no agriculture before the advent of the Bronze Age, at a time when local ceramic production appeared after metallurgy. The concept of an 'Empty Quarter of the Holocene' (Uerpmann M. 1992, 2003) no longer applies; recent discoveries illustrate this well in a high variability and diversity of cultures, techniques and traditions during the Early Holocene.

\section{Acknowledgements}

We wish to thank our esteemed colleagues Marie-Louise Inizan, Margarethe Uerpmann and Philipp Drechsler for fruitful discussions on this specific topic, which began well before the 2012 ESF Exploratory Workshop in Lyon.

\section{References}

Abbès, F. 2003. Les outillages néolithiques en Syrie du Nord, méthode de débitage et gestion laminaire durant le PPNB. (BAR S1150). Oxford: Archaeopress.

Cauvin, J. 1968. Fouilles de Byblos IV: les outillages néolithiques de Byblos et du littoral libanais. Paris: Maisonneuve.

Cauvin, J. 1997. Naissance des divinités, naissance de l'agriculture. Paris: CNRS Éditions.
Charpentier, V. 1991. La fouille du campement préhistorique de Ra's al Junayz 37 (RJ 37): Sultanat d'Oman. Paléorient 17/1: 127141.

Charpentier, V. 1996. Entre sables du Rub' al Khali et mer d'Arabie, préhistoire récente du Dhofar et d'Oman: les industries à pointes de 'Fasad'. PSAS 26: 1-12.

Charpentier, V. 2008. Hunter-gatherers of the 'empty quarter of the early Holocene' to the last Neolithic societies: chronology of the late prehistory of south-eastern Arabia (8000-3100 BC). PSAS 38: 59-82.

Charpentier, V. \& Crassard, R. 2012.

Prehistoric sites from Ramlat Fasad,

Sultanate of Oman - Charles

Hendricks' collection, 1972. Muscat:

Expertise for the Ministry of Heritage

and Culture, Sultanate of Oman.

(Unpublished.) 


\section{CHARPENTIER AND R. CRASSARD}

Charpentier, V., Cremaschi, M. \& Demnard, F. 1997. Une campagne archéologique sur un site côtier du Ja'alan: al-Haddah (BJD-1) et sa culture matérielle (Sultanat d'Oman). PSAS 27: 99-111.

Charpentier, V., Berger, J-F., Crassard, R., Lacaze, M. \& Davtian, G. 2012. Prehistory and palaeo-geography of the coastal fringes of the Wahiba Sands and Bar al-Hikman, Sultanate of Oman. PSAS 42: 57-78.

Crassard, R. 2008a. La Préhistoire du Yémen. Diffusions et diversités locales, à travers l'étude d'industries lithiques $d u$ Hadramawt. (BAR International Series S1842). Oxford: Archaeopress.

Crassard, R. 2008b. The 'Wa'shah method': an original laminar debitage from Hadramawt, Yemen. PSAS 38: 3-14.

Crassard, R., Petraglia, M.D., Parker, A.G. \& Parton, A. et al. forthcoming. Beyond the Levant: first evidence of a Pre-Pottery Neolithic incursion into the Nefud Desert, Saudi Arabia. PLoS ONE

Cremaschi, M. \& Negrino, F. 2002. The Frankincense of Sumhuram: palaeoenvironmental and prehistorical background. Pages 325-363 in Avanzini, A. (ed.), Khor Rori report 1 (Pisa, Edizioni Plus/Università di Pisa).

Drechsler, P. 2009. The Dispersal of the Neolithic over the Arabian Peninsula. (BAR International Series S1969). Oxford: Archaeopress.

Edens, C. 1982. Towards a definition of the western Rub'al-Khali 'Neolithic'. Atlal 6: 109-124.

Edens, C. 1988. Archaeology of the Sands and adjacent portions of the Sharqiyah. Pages 113-130 in Winser, N. \& Dutton, R.W. (eds.), The Scientific results of the Royal
Geographical Society's Oman Wahiba Sands Project 1985-1987. (Muscat, Office of the Adviser for Conservation of the Environment)

Fernandes, V., Alshamali, F., Alves, M., Costa, M.D., et al. 2012. The Arabian Cradle: Mitochondrial Relicts of the First Steps along the Southern Route out of Africa. The American Journal of Human Genetics 90: 1-9.

Hilbert, Y., Rose, J. \& Roberts, R. 2012. Al-Hatab Late Palaeolithic core-reduction strategies in Dhofar, Oman. PSAS 42: $1-18$.

Inizan, M-L. 1980. Sur les industries à lames de Qatar. Paléorient 6: 233-236.

Inizan, M-L. 1988. Préhistoire à Qatar, Vol. 2. Paris: Éditions Recherche sur les Civilisations.

Inizan, M-L., Reduron-Ballinger, M., Roche, H. \& Tixier, J. 1995. Technology and Terminology of Knapped Stone. Préhistoire de la Pierre Taillée, Vol. 5. Nanterre: CREP.

Kallweit, H. 2003. Remarks on the Late Stone Age in the U.A.E. Pages 56-64 in Potts, D., Al Naboonah, H. \& Hellyer P. (eds.), Archaeology of the United Arab Emirates. Proceedings of the First International Conference on the Archaeology of the U.A.E. (London, Trident Press).

Kapel, H. 1967. Atlas of the Stone-Age Cultures of Qatar. Aarhus: Aarhus University Press.

McClure, H.A. 1994. A new Arabian stone tool assemblage and notes on the Aterian Industry of North Africa. $A A E$ 5: $1-6$.

Masri, A.H. 1997. Prehistory in northeastern Arabia, the problem of interregional interaction. London: Kegan Paul International.

Millet, M. 1988. Survey of the Sharjah coast. Archaeological Survey in Sharjah Emirate (U.A.E.). Sharjah Archaeology 4: 23-30.

Pullar, J. 1974. Harvard Archaeological Survey in Oman, 1973: I - Flint sites in Oman. PSAS 4: 33-48.

Rose, J.I. 2010. New light on human prehistory in the Arabo-Persian Gulf Oasis. Current Anthropology 51: 849883.

Scerri, E. 2012. A new stone tool assemblage revisited: reconsidering the 'Aterian' in Arabia. PSAS 42: 357-370.

Uerpmann, M. 1992. Structuring the Late Stone Age of Southeastern Arabia. AAE 3: 65-109.

Uerpmann, M. 2003. The dark Millennium Remarks on the final Stone Age in the Emirates and Oman. Pages 74-81 in Potts, D., Al Naboonah, H. \& Hellyer P. (eds.), Archaeology of the United Arab Emirates. Proceedings of the First International Conference on the Archaeology of the U.A.E. (London, Trident Press).

Uerpmann, H-P., Potts, D. \& Uerpmann, M. 2009. Holocene (re-)occupation of eastern Arabia. Pages 205-214 in Petraglia, M.D. \& Rose, J.I. (eds.), Evolution of human populations in Arabia: paleoenvironments, prehistory and genetics (Dordrecht, Springer).

Zarins, J. 2001. The Land of Incense: Archaeological work in the Governorate of Dhofar, Sultanate of Oman, 1990-1995. Muscat: Sultan Qaboos University Publications. 